\title{
Destinos Migrantes: Representações Simbólicas, Histórias de Vida e Narrativas
}

Julie A. Cavignac A investigação sobre a memória e as narrativas dos migrantes oriundos do interior do Rio Grande do Norte que residem na Zona Norte de Natal partiu da preocupação em saber se a cultura dessa população recém-urbanizada - cuja literatura oral é uma de suas principais expressões - permanece intacta ou se ela sofre transformações num novo quadro social. Estudar a produção narrativa de uma comunidade de migrantes é também recolher o discurso ligado ao passado e à origem, através de histórias de vida, de lembranças etc. A identidade destas novas comunidades passa primeiramente pela referência à uma cultura e/ou uma história comum ${ }^{\text {. }}$.

Antes de analisar as histórias contadas por membros deste grupo, foi preciso investigar a formação sócio-econômica da região, a fim de compreender seus fenômenos migratórios. No entanto, devido à escassez de literatura e pelo fato de existirem poucos estudos sobre as formas migratórias recentes do Nordeste, mostrou-se necessário partir para uma pesquisa de campo, isto é, realizar um estudo etnográfico. Pensamos então em coletar histórias de vida e reconstruir a 'história' da Zona Norte a partir das experiências vividas pelos migrantes que a povoam (cf. Cavignac 1997c). Por isso, lembraremos a importância do crescimento populacional e do desenvolvimento da região, antes de apresentar o nosso método e de abordar a relação dos textos junto à migração para, finalmente, avaliar as modificações ocorridas no corpus narrativo.

São múltiplas as referências às "histórias de antigamente": romances e folhetos de cordel, estórias de trancoso ${ }^{2}$, contos, lendas de fundação de cidades etc. Além de serem marcos da memória individual, apresentando-se como 
estas "histórias" servem de âncora para a história do grupo local. Graças à rememoração e à leitura das narrativas, os migrantes reativam experiências e valores comuns, que são os de uma cultura rural, geralmente denegrida no meio urbano. Mas é através destas formas narrativas que os migrantes interpretam os acontecimentos que marcaram suas vidas e o mundo que os rodeia. Assim, os folhetos de cordel, os romances e os contos são uma via de aprendizagem da realidade, na qual os problemas sociais, políticos e econômicos são traduzidos em uma linguagem poética e formatados em uma estrutura narrativa conhecida por todos (Cavignac 1997). Atualmente, esses 'textos tradicionais' parecem permanecer com uma função identitária: apesar de terem desaparecido da prática cotidiana, não existindo mais o seu contexto tradicional de enunciação, mostram-se adaptáveis ao ambiente de vida citadino. $O$ 'interior' não é mais a referência, passando a ser substituído pela Zona Norte, que é agora o novo lugar de vida. Veremos, assim, que junto às mudanças ocorridas nessas últimas décadas, novos textos aparecem. Estes são ligados, geralmente, a uma experiência migratória positiva e correspondem a uma apropriação do espaço e da história do local.

\section{O "OUTRO LADO DO RIO"}

Se as culturas urbanas têm sido pouco estudadas no Brasil, as cidades do Nordeste foram as mais esquecidas pelos antropólogos (Magnani 1996). Raros são os estudos etnográficos recentes que tratam da migração nordestina. O trabalho de E. Durham, já bastante antigo e mesmo analisando uma realidade diferente, permanece sendo uma referência principal, à qual se agregam outras pesquisas sobre a presença dos nordestinos em São Paulo ou as novas formas de migração (Magnani 1996; Menezes 1992; Morice 1993; Rigamonte 1996). Porém, nesses últimos anos, não se pode deixar de notar o crescimento rápido da região, que conheceu uma urbanização acelerada. No Rio Grande do Norte, por exemplo, já em 1991 quase 70\% da população total do Estado era urbana. As principais cidades, Natal e Mossoró, pólos atrativos, não pararam de crescer e viram se desenvolver extensas zonas suburbanas, passando às vezes do limite do município, como é o caso de Parnamirim. Em vinte anos, a população de Natal dobrou, passando de 264.379, em 1970, para 656.037 habitantes, em 1996 (IDEC 1996).

Nos anos 70, com o fim do "milagre econômico", percebeu-se uma mudança na configuração 
migrantes, ocasionando as migrações de retorno; são elaboradas políticas de fixação da população com a finalidade de conter os fluxos migratórios em direção ao eixo Rio/São Paulo, sendo verificado também um crescimento do exôdo rural para as capitais nordestinas. Foi nesse mesmo período que o processo de crescimento urbano em Natal foi acelerado. Segundo o IBGE, entre 1970 e 1980, mais de $70 \%$ do crescimento populacional da cidade ocorreu em função das migrações; entre 1980 e 1991, o saldo migratório passa a ser de 50\% (Vidal 1998:22). Ainda no final dos anos 60, em Natal, e, sobretudo, na Zona Norte, foi iniciada a construção de conjuntos habitacionais patrocinados pelos governos estadual e federal, tendo como prioridade a habitação popular (Vidal 1998:48). Hoje é a localidade que agrupa o maior número da população de baixa renda.

Localizando-se na margem esquerda do rio Potengi, vizinho ao município de São Gonçalo do Amarante, a chamada "Zona Norte" conhece, desde os anos 60-70, uma mudança radical: a vila de Igapó, tomada como exemplo, continuou a ter suas características 'arquiteturais' de uma cidade do interior, enquanto via a cidade crescer. Mesmo não dispondo de dados estatísticos suficientes para a determinação da origem populacional da Zona Norte, esta parece ser, em grande parte, habitada por moradores oriundos dos municípios do litoral norte do Estado e das regiões das salinas. São os migrantes mais antigos, pois chegaram no início da "construção" da Zona Norte. A eles se agregam os "migrantes de sempre"; sertanejos fugindo das inúmeras secas, que se estabelecem definitivamente na cidade, mas que conservam fortes elos com as regiões de origem. Destacam-se também, no conjunto da população, os "migrantes de retorno" que, em sua maioria, voltam de uma migração efetuada para a região centro-sul do país. Enfim, um grande número da população sem renda conhece uma mobilidade importante: membros da família são acolhidos durante um tempo indeterminado e retribuem a ajuda que eles recebem participando das despesas da casa. A busca de um trabalho é geralmente o fator de declínio da migração; a pessoa pode, a qualquer momento voltar ao seu lugar de origem ou partir para um outro destino. A imprevisibilidade e a precariedade dos meios de vida, a busca de uma oportunidade, junto a um espírito aventureiro, levam o indivíduo a migrar. Por isso, fica complicado querer quantificar essa realidade que só pode ser percebida através das histórias de vida

Apesar dos incentivos, poucas indústrias têm funcionado na área que se firmou, desde os anos oitenta, como uma zona habitacional e de comércio. Antes, a construção dos conjuntos habitacionais tinha mudado, profundamente, a paisagem do local. O primeiro conjunto construído foi o Amarante, durante o governo do Monsenhor Walfredo Gurgel (1964/1970). Outros se seguiram 
rapidamente: Pajuçara, Igapó, Nova Natal, Panatis etc. foram construídos para atender às necessidades de moradia de uma população recém-urbanizada ou de origem rural, pertencente à camada mais pobre da população ${ }^{4}$. Nessa época, foi desativada a antiga ponte da estrada de ferro, que ligava Natal à Zona Norte. A nova ponte, devido ao aumento do trânsito, sobretudo nos anos noventa, teve dobradas as suas vias de acesso. Em 1987, viviam aproximadamente 60.000 moradores; hoje o número de habitantes passa dos 200.000 , o que significa que mais de $30 \%$ da população total da capital

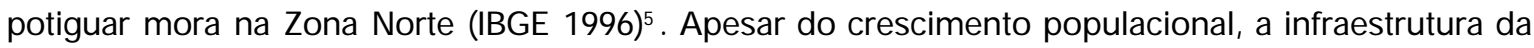
região ainda é precária (saneamento básico, transporte, saúde, segurança, serviços, educação etc.). A igreja teve um papel importante na implantação de creches, escolas e associações de moradores. Mesmo sem muitos dados sobre a questão, pode-se afirmar que a maior parte dos migrantes ocupam os empregos menos qualificados: muitos homens trabalham no setor da construção civil ou dos transportes e muitas mulheres são empregadas domésticas (Agier 1995:82; Clementino 1995:317; Morice 1993), ocupando-se ainda com as atividades de costureiras, manicures, diaristas sem carteira assinada, artesãos, vendedores ambulantes, empresas de fundo de quintal etc. Hoje, a Zona Norte apresenta-se como a melhor opção, do ponto de vista financeiro, para se morar em Natal. Mas o estigma de subúrbio sobrevive às campanhas (privadas e públicas) de revalorização do local.

Uma vez que o migrante, ao adquirir o seu imóvel, deixa o estatuto de "estrangeiro", torna-se morador do conjunto habitacional, isto é, um habitante. Porém, esses antigos camponeses não se tornaram citadinos de uma hora para outra. A Zona Norte tem como característica principal estar situada em um espaço que antes se definia como rural e que, ainda hoje, mistura uma paisagem urbana com traços de uma vida campestre. A proximidade geográfica explica também as intensas relações existentes entre a Zona Norte e as zonas rurais contíguas. Muitas localidades, como São Gonçalo do Amarante, Macaíba ou Extremoz, foram absorvidas, como também as áreas litorâneas mais próximas (Redinha e Genipabu). Os moradores dos numerosos conjuntos populares podem, ainda, exercer atividades agrícolas perto de suas residências (como por exemplo, cultivar um roçado ou criar animais) ou mesmo longe de suas moradas, indo trabalhar no campo durante a semana ${ }^{6}$. Uma grande parte da população, mesmo sem exercer atividade econômica na zona rural, volta aos seus locais de nascimento durante os períodos festivos ou eleições. Para entender as mudanças culturais ocorridas durante a migração e a adaptação ao local, precisamos nos deter aos textos narrativos. Uma vez instalados, os locutores criam novos textos inspirando-se no modelo tradicional. Assim, longe de uma ruptura, notamos uma continuidade no processo de transmissão da tradição oral ${ }^{7}$. 


\section{A LITERATURA ORAL: SUPORTE DA MEMÓRIA? ${ }^{8}$}

Antes de analisar algumas narrativas, precisamos esclarecer certos pontos teórico-metodológicos norteadores da nossa pesquisa, que procura analisar diferentes tipos de textos: os que são formalizados numa narrativa de ficção ou história de vida, e os que constituem o discurso cotidiano. Assim, se o estudo da literatura oral, que durante muito tempo despertou o interesse dos folcloristas e dos historiadores, ficou fora dos grandes questionamentos antropológicos do Brasil atual, há pouco surgem nas investigações sobre memória, lembranças e vocações do passado narrativas multiformes, difíceis de serem manipuladas pelo pesquisador. Se quase todos os antropólogos trabalham com a "matéria discursiva" (discursos nativos, histórias de vida, lembranças da infância, narrativas, entrevistas semi-diretivas etc.), poucos se questionam sobre a ausência de um método adequado e de uma definição precisa das ferramentas a serem utilizadas no momento da análise. Mais precisamente, faltam elementos para realizar estudos sobre a questão narrativa em um contexto social pouco estudado pelos antropólogos brasileiros, mas bastante investigado pelos folcloristas, romancistas e críticos literários: o Nordeste.

Assim, para poder iniciar a nossa investigação, parece importante desenhar o 'estado da arte', quer dizer, definir as grandes linhas que inspiraram o nosso método ${ }^{9}$. Através do estudo comparado de textos que, geralmente, adotam uma forma narrativa, e enunciados orais não formalizados, onde encontram-se 'pedaços de mitos', tentar-se-á perceber como os potiguares ${ }^{10}$ reelaboram sua história e sua identidade. Do mesmo modo, será visto como é possível chegar a uma representação bastante uniforme e original do passado, bem como encontrar categorias de pensamento que ordenam o mundo social e natural (Durkheim 1985).

A terminologia utilizada pela Antropologia para designar o campo de estudo da narrativa oral não é satisfatória: a tradição oral ou o folclore não propõem conceitos operatórios. Os termos designam tanto as formas de transmissão dos textos quanto as produções literárias encontradas em uma sociedade. Além disso, não existe uma teoria unificada para o estudo das tradições orais e cada disciplina tenta elaborar seus próprios instrumentos e métodos de análise, ignorando os resultados das outras. Limitar-nos-emos aqui a apontar os problemas colocados ao antropólogo 'em campo', na hora da coleta e análise do material literário. Três dificuldades essenciais podem ser apontadas. Primeiro, há poucos estudos etnográficos sobre o Nordeste, sobretudo o interior. Segundo, há uma indeterminação terminológica, ligada à natureza do objeto (texto, discurso, 
tradição, literatura oral, folclore etc.). Enfim, na antropologia 'clássica', deixando-se de lado a obra de Lévi-Strauss, não há estudos teóricos sobre a "matéria narrativa" (Lévi-Strauss 1996: 153)11.

No Brasil, se muitos trabalhos descrevem as minorias étnicas, em especial analisando suas formas religiosas ou apontando para reivindicações de uma identidade e/ou de território, poucos se dedicam à percepção das mutações das culturas rurais. Com exceção das pesquisas influenciadas pela antropologia americana - os "estudos de comunidade" em voga nos anos 50 - e algumas pesquisas pioneiras ${ }^{12}$, há pouco espaço para essas temáticas na antropologia brasileira atual. Quando, finalmente, o Nordeste se torna objeto de pesquisa, o foco das preocupações é centrado nos laços sócio-econômicos ou nos contratos de trabalho, sobretudo no espaço das plantações de cana-deaçúcar (Lanna 1995: 24). Assim, o sertão nordestino e a questão da narrativa foram abandonados aos folcloristas e aos historiadores amadores, tendo sido considerados como objetos indignos de uma investigação sociológica. A realização destes estudos foi, ainda, inibida pelo estigma das investigações pioneiras sobre o Nordeste e sua tradição oral: Euclides da Cunha para o sertão, Sílvio Romero e Luís da Câmara Cascudo para um estudo romântico da literatura oral ${ }^{13}$. O sertão, então, parece estar ligado apenas a assuntos que se mostram clássicos: a seca, o fanatismo religioso, o cangaço etc. Por outro lado, e de um modo geral, o conceito de "oralidade" é utilizado há bastante tempo sem que os pesquisadores se interessem em definir os limites e a natureza dos seus objetos de estudo. Inventada pelos folcloristas, a terminologia foi aproveitada e retomada pelos antropólogos que a utilizam junto ao conceito de tradição. Desde 1881, Paul Sébillot utiliza o termo "literatura oral" e Pierre Saintyves lembra que o "saber do povo" se transmite de boca em boca. O conto popular, gênero narrativo mais estudado pelos folcloristas, aparece, desde então, como uma obra anônima, porque nascida da memória coletiva e pertencente a todas as camadas sociais.

Descritas como simplórias e reveladoras de um estado de inocência, as narrativas parecem não justificar um estudo sociológico que lhes tome como objeto. Assim, nas ciências humanas não há um consenso nem do ponto de vista teórico nem metodológico para os estudos da tradição oral (Langdon 1999). Além disso, o fenômeno da oralidade agrupa um grande número de fatos culturais: a literatura oral nas suas diferentes formas - em verso ou em prosa, cantada, declamada, improvisada etc. - , as genealogias, os rituais - sobretudo as fórmulas mágicas - , costumes, receitas e técnicas transmitidas pelas gerações passadas (Boyer 1988; Detienne 1979). Percebe-se, então, que as produções orais ajudam a manter a memória coletiva, explicam o presente e permitem perceber as mudanças culturais. A memória é trabalhada a cada geração, onde são reavaliados os 
conteúdos e as informações que a tradição oral transmite. Sem perder sua função identitária, a memória é voltada para o presente (Goody 1979). Da mesma forma, a atualização das narrativas pela performance oral possibilita compreender a continuidade das tradições narrativas (Zumthor 1997:53). Com exceção dos textos 'ensinados' que dão uma explicação da História - mitos de fundação, lendas históricas ou as crônicas - , os mitos e os contos, juntos aos ritos e aos costumes, constituem uma herança oral integrada que é 'retrabalhada' a cada locutor. Assim, não se pode esperar encontrar o reflexo fiel do passado nas produções literárias de um grupo particular. É preciso analisar estas produções narrativas como um discurso formalizado culturalmente, levando em conta a liberdade criativa do contador e a ação do tempo, sem esquecer, portanto, que se tratam de obras de ficção. Diante destas proposições, o texto oral poderia ser definido como uma categoria do discurso nativo ou uma narrativa etnográfica determinada que permite atingir não uma realidade presente ou passada, mas a sua modelização, na qual a oralidade exerce o papel determinante na perpetuação deste discurso formalizado. Essa proposta aproxima-se do método estruturalista (Lévi-Strauss 1974).

Os estudos clássicos sobre a poesia popular do Nordeste brasileiro não têm conseguido, a contento, perceber a riqueza do material encontrado sob uma perspectiva teórica, deixando mais registros e antologias do que análises propriamente ditas ${ }^{14}$. Assim sendo, como dar conta da multiplicidade dos gêneros poéticos? Por exemplo, o poeta de cordel pode ser, ao mesmo tempo cantador de viola, glosador, contador de estória, cantor, decorar romances e dramas etc. Ele passa de um gênero a outro sem nenhuma dificuldade; gêneros que são tipos poéticos e literários distintos e que, por isso, na hora da análise, precisariam de um tratamento específico (Muzart 1997; 1999). Desse modo, o pesquisador interessado nos contos maravilhosos deveria jogar fora tudo que não pertence à categoria de 'conto'? Mas se junto ao conto é freqüente encontrar lendas, provérbios, parlendas, cantigas de roda, canções, romances da pura tradição ibérica, fica bastante difícil reconhecer as fronteiras entre os gêneros narrativos. Em outras palavras, e para retomar uma discussão clássica, onde devemos situar os limites entre o mito e o conto? (Detienne 1979) Os dois podem ser definidos como ficções narrativas, sendo o segundo descrito, geralmente, como uma degenerescência do primeiro. O conto, então, seria de uma natureza similar, mas não teria o caráter sagrado do mito. Atualizando-se a cada enunciação, ele seria percebido como uma estória que perderia sua força, servindo apenas para divertir ou fixar a experiência humana. Todos os estudiosos do assunto, porém, concordam em afirmar que essa distinção parece pouco explicativa: 
mostra gêneros literários correspondendo às categorias próprias da sociedade investigada ou às do pesquisador? (Belmont 1986:56; Boyer 1982:6; Goody 1979:210; Propp 1983:27; Lévi-Strauss 1974: 140; Zumthor 1983).

Os trabalhos pioneiros de Propp (1965), que insistem sobre a recorrência formal dos contos de encantamento e sobre a possibilidade de utilização de uma perspectiva comparativa na análise dos mesmos inspiraram diretamente Lévi-Strauss (1974: 235-265) na elaboração do seu método estruturalista ${ }^{15}$. Porém, mesmo Lévi-Strauss demonstrando a possibilidade da utilização do seu método para outras narrativas que não fossem os mitos, poucos estudiosos seguiram os seus ensinamentos (Belmont 1970; 1986). Parece que a literatura oral foi apagada pela análise estruturalista, por considerála como 'parent pauvre' do mito. Afinal, a perfeição e a amplitude do modelo estrutural inibem qualquer um! De um modo geral, pelo menos na Antropologia, a análise narrativa parece ter sido 'esmagada' pela explicação estruturalista, preocupada, em primeiro lugar, em procurar esquemas universais do pensamento humano, separando assim as sociedades das suas produções literárias. Durante décadas, o mito foi, dentro das produções orais, o único objeto legítimo de investigação antropológica, revelando as elaborações simbólicas mais profundas das populações estudadas (LéviStrauss 1974: 235-265). Atualmente, com a crítica à pretensão universalista do estruturalismo e com a abertura da disciplina a outras vias de explicação, torna-se possível adotar uma perspectiva pluridisciplinar, voltada para a sociedade produtora da sua História ${ }^{16}$. A antropologia eliminou as visões românticas associadas às sociedades primitivas e os estudiosos constataram a presença da História e da Antropologia em um mesmo campo de pesquisa - o da memória.

Uma outra via, mais recente, de apreensão da literatura oral é pelo estudo da performance das produções literárias e poéticas, supondo um estudo preliminar da língua. A etnolinguística, que estuda as relações entre uma língua determinada, a cultura e a sociedade que a ela estão ligadas, é a disciplina que se aproximaria mais do estudo das produções discursivas de um grupo, de um ponto de vista antropológico. Considerando a importância dos modos de transmissão, os 'novos folkorists" americanos elaboram um método de investigação fundado na performance (Bauman 1975; Tedlock 1971, 1983, 1988). Por outro lado, seguindo o caminho aberto por Claude Lévi-Strauss, muitos antropólogos recorrem também à semiótica, centrada na análise do discurso e das operações cognitivas. Nesta abordagem, a investigação das estruturas discursivas profundas permitiria a apreensão de sua significação. Essas perspectivas, que fornecem um método de investigação preciso, no entanto, são bastante técnicas e centradas principalmente na língua e nas formas de transmissão 
do saber (Langdon 1999). Mesmo associando os aspectos sócio-culturais das produções linguísticas, elas não conseguem integrar o estudo dos sistemas de signos ao do material etnográfico e, sobretudo, não levam em conta a especificidade da análise das produções literárias que adotam uma forma narrativa. O termo etnoliteratura seria mais apropriado, mas não foi erguido em especialidade e, ainda assim, não é suficiente para tratar das especificidades da narrativa; por exemplo, a utilização de fórmulas, a repetição ou as ligações do oral com o escrito etc.

Concebido como suporte da memória do grupo ou das suas produções simbólicas, o texto oral ganha novos adeptos com o revival dos anos setenta e a crise de objeto da antropologia. Com isso, ao mesmo tempo em que são redescobertas as tradições das populações camponesas européias, até então estudadas pelos folcloristas, novos estudos aparecem entre as 'nações jovens', tendo como enfoque principal as modificações ocorridas durante o processo colonizador. Assim, as sociedades exóticas tornam-se campo de investigação 'naturais' dos antropólogos europeus e americanos, principalmente a partir da generalização dos movimentos de libertação das antigas colônias, havendo também o surgimento de uma antropologia nativa e, às vezes, nativista. Com este retorno dos antropólogos ocidentais ao velho terreno dos folcloristas, a disciplina teve que elaborar novos instrumentos de investigação, como também reintroduzir a dimensão temporal nos estudos dos textos da tradição oral. Uma da vias mais ricas que, às vezes, integra o estudo do texto literário, resulta da aproximação da Antropologia com a História (Le Goff 1996; Price 1983; Mattoso 1999). Pode-se perceber este movimento, sobretudo, com o surgimento dos trabalhos da história oral e dos estudos com o objetivo explícito de resgatar a memória dos excluídos: histórias de vida adaptadas pelos pesquisadores que eram apresentadas como documentos autobiográficos ${ }^{17}$. Inventado na França, o termo "etno-texto" designa qualquer produção discursiva, independente da sua forma, elaborada pelo grupo e que visa reforçar a sua identidade, através da rememoração (Bouvier 1992) ${ }^{18}$. No Brasil, poucos antropólogos seguiram essa pista. Os especialistas da literatura, adotando os métodos e os conselhos dos antropólogos, investigam há décadas o estudo da tradição oral, sobretudo nordestina. Em grande parte discípulos de Paul Zumthor (1997), eles apontam para a vocalidade das literaturas orais, utilizando-se dos métodos e perspectivas das ciências humanas (Ferreira 1996; Santos 1997; Santos in Bernd e Migozzi 1997: 35-37) ${ }^{19}$. Associandose a este movimento, que não deixa de levar em conta a dimensão literária do texto, tomamos como pressuposto que as narrativas enunciadas pelos migrantes da Zona Norte visam reavaliar a identidade de um grupo fraccionado e fragilizado pelas experiências pessoais geralmente 
desgastantes. Analisando as histórias de vida ou as produções literárias, notamos uma constante: os textos são tentativas de racionalizar experiências e trajetórias de vida, como também de elaborar e reforçar identidades coletivas ameaçadas pela mudança ocorrida após a migração. Assim, longe de reproduzir um corpus narrativo fixo, os locutores reinventam histórias: quer sejam textos narrando o passado do bairro, quer sejam contos ou ainda trajetórias pessoais, não conseguimos atingir 'a' verdade histórica, mas uma realidade pensada e às vezes sonhada pelos contadores.

\section{DESTINOS MIGRANTES}

Graças à pesquisa etnográfica e à coleta de um corpus essencialmente narrativo, conseguimos versões de uma realidade cotidiana dessa população recém-urbanizada. Os textos coletados, 'performados' ou escritos, foram selecionados de acordo com o tema da pesquisa e confrontados com os seus contextos de enunciação ou de produção específicos. Assim, pode-se entender os textos depois da comparação com as outras criações culturais, como as várias formas de poesia, as rezas, as práticas medicinais, a percepção do espaço, as festas de padroeiro, as romarias (Cavignac 1994 e 1997b) etc. Mesmo pertencendo a outros níveis da cultura, essas criações simbólicas adotam quase sempre a forma de narrativas, cujas estruturas já são conhecidas. Parece interessante, então, usar um mesmo método para analisar produções culturais diversas de uma sociedade ${ }^{20}$.

Porém, acontece que os migrantes não chegam a formar um grupo, e, portanto, não se trata de uma totalidade homogênea. Eles nem chegam a representar uma "comunidade", mesmo morando em uma área delimitada; nem uma classe, ainda que pertençam às camadas sociais menos favorecidas. Apenas fazem parte da população natalense e dividem características comuns, como a de ter migrado pelo menos uma vez na vida e a de morar na mesma zona periférica de Natal. São indivíduos que conheceram trajetórias de vida e experiências migratórias diversas. Os problemas vivenciados por este grupo de migrantes, ligados à vida periférica e à existência em uma sociedade contemporânea, podem ser resumidos em alguns aspectos descritos nas palavras de Ana Maria Doimo (1995:91):

“O desenraizamento das massas e a atomização da existência, a complexa divisão do trabalho e a fragmentação dos papéis sociais, o apego a práticas seculares e o desencantamento do mundo, a monetarização das relações e a perda do sentimento de solidariedade, o avanço da racionalidade das instituições e o desapego às relações de tipo primário, especificamente as referidas à família e à religião." 
O migrante aparece como um excluído social (Durham 1982:220) e, politicamente falando, tenta reproduzir no espaço urbano, como alternativa integradora, alguns dos padrões culturais que caracterizam a comunidade de meio rural. A relação indivíduo/sociedade é feita, então, através dos grupos de relações primárias (família, vizinhança, congregação religiosa) que aparecem como tentativas de reconstrução da sociabilidade antiga. Porém, na Zona Norte, a reunião entre vizinhos e família próxima é dificultada pela estrutura urbana dos conjuntos habitacionais. A vizinhança às vezes é, ainda, vista como perigosa, no caso dos moradores dos conjuntos vizinhos às favelas. Por outro lado, a diversidade das práticas religiosas, com a importância crescente das seitas protestantes nos bairros pobres da cidade, pode ser entendida como uma tentativa de demarcação sócio-econômica.

Um trabalho sobre a memória dos migrantes é então dificultado pela desintegração do grupo familiar, dos laços com a comunidade de origem ou até mesmo pela mudança acontecida na identidade pessoal do locutor. Mas, por um outro lado, a memória e a narração subjetiva dos fatos permitem resgatar a versão da migração no olhar do falante. Assim, retomando as idéias de Maurice Halbwachs (1990), pensamos que a memória não é uma simples reprodução dos fatos e dos acontecimentos, mas um produto de uma elaboração singular de um indivíduo sobre a sua própria experiência. A pessoa repensa e reelabora o passado com a visão presente. Os marcos da sua memória são, desse modo, os eventos importantes na sua vida: casamento, nascimento dos filhos, mudança de local de moradia, do trabalho, morte de uma pessoa etc. Fixamos então nossa atenção em histórias de vida peculiares, para depois poder tirar algumas conclusões sobre as possíveis transformações de uma cultura tradicional, como a das zonas rurais do Rio Grande do Norte, no cotidiano urbano. Para isso tivemos que analisar algumas histórias de vida, aproximandonos dos trabalhos recentes de pesquisadores que investigam a realidade brasileira (especificamente nordestina) e a das migrações (Menezes 1992; Cabanes 1995; Sigaud 1993; Ajara 1993). O método biográfico parece ser o mais indicado para um estudo sobre os migrantes. Nesse sentido, M. Menezes (1992:165) avança que

"as histórias de vida revelam universos diversos e constituem, a nosso ver, um material rico para analisar como esta diversidade é elaborada por seus produtores."

Assim, o migrante avalia a sua trajetória de vida e nós podemos resgatar fatos, percepções, avaliações, perspectivas de vida, visões do mundo e opções do migrante (Menezes 1992:167). Na 
verdade, é difícil estabelecer uma regra para as migrações, pois estas são muito variáveis. Porém, é possível afirmar que pelo menos dois fatores importantes determinam uma pessoa a migrar: a possibilidade de trabalho e a existência de um parente morando no local. Na pesquisa realizada com os migrantes da Zona Norte, verificamos que, das pessoas entrevistadas, somente dois homens efetuaram uma ou mais migrações sem ser acompanhados de um parente ou sem ter família no lugar de migração² . $^{2}$

Mostra-se então a necessidade de se realizar uma pesquisa etnográfica para descobrir o universo de referência dos migrantes, bem como as possíveis estratégias dos candidatos à partida. Apesar das dificuldades em encontrar uma regra para as migrações e os locais de destino, tem-se que analisar as histórias de vida detalhadamente para dar conta da multiplicidade dos perfis dos migrantes. A imagem caricatural do pau-de-arara chegando em São Paulo se desmancha frente à diversidade de percursos individuais que foram levantados durante a pesquisa. Porém, atrás desta multiplicidade de percursos, podem ser encontradas algumas regularidades temáticas (a família, o trabalho, a moradia), tanto que esses relatos de vida podem ser lidos como 'estórias', tendo uma organização narrativa e temática semelhantes.

O que aparece como traço comum na maior parte das histórias de vida é que, durante a migração, o grupo não se desagrega. Às vezes, mesmo a sociabilidade fundada no modelo tradicional da família extensa se aplica a outros tipos de relacionamentos ${ }^{22}$. Na realidade, constatamse uma forte solidariedade e a existência de obrigações recíprocas entre os membros do grupo. Estes aspectos podem se materializar, por exemplo, na hospedagem de um parente, ou de um dos seus amigos, por um período variável e nem sempre especificado. Este elo permite também conceder uma ajuda moral ou afetiva, no caso de um evento importante na família (nascimento, doença grave, morte, divórcio etc.). Pode se tratar também de uma ajuda material. Neste caso, os parentes próximos (pais e irmãos) são solicitados e dificilmente podem deixar de ajudar. Muitas vezes, e apesar da distância geográfica, as relações continuam intactas entre os que ficam e os que vão embora. Isto é visível nas histórias de vida, evidenciando que no processo de migração existe uma lógica fundada na solidariedade familiar (Cabanes 1995; Menezes 1992; Sarti 1995). Se os principais motivos da migração são econômicos e familiares, no caso das pequenas migrações (intraestaduais), elas são também motivadas pela procura de assistência, no caso de seca, ou de serviços (saúde, educação, administração etc.).

Os migrantes, em seus deslocamentos, geralmente conhecem uma urbanização progressiva, deslocando-se da zona rural para a zona urbana, de uma pequena cidade do interior ou do litoral 
para Natal, fazendo também, concomitantemente a estas, várias pequenas migrações. Essas podem ser combinadas com uma grande, longe do Nordeste (geralmente para o Sudeste ou a Amazônia). Na sua grande maioria, não são migrações totalmente satisfatórias, porque as pessoas voltaram depois de um tempo longo ou curto (podendo variar de alguns meses a mais de dez anos).

Três momentos merecem ser destacados nas histórias de migração. Primeiro, há uma referência a um problema obrigando a pessoa, ainda jovem, a "cuidar do seu destino" e/ou a tomar a responsabilidade da família, pela morte dos pais, separação, problemas financeiros etc. Forças maiores são também evocadas, por exemplo a seca, como sendo a origem da desgraça e da partida. No caso dos homens, o primeiro emprego é, geralmente, conseguido com a ajuda dos parentes e se situa no ramo do trabalho informal (Agier 1995:97). Como nas narrativas ${ }^{23}$, existe quase sempre uma romantização do tema da partida e do exílio nas histórias de vida. Além disso, o desejo de "subir na vida" e/ou uma libertação da tutela do pai escondem as razões econômicas da migração. Em uma segunda fase há a construção da própria família, com a evocação das dificuldades ligadas ao trabalho, à criação dos filhos e à vida longe do local do nascimento. Aí podem ocorrer várias migrações e há uma grande mobilidade residencial. A dificuldade em se adaptar a uma nova realidade, em poder suportar uma vida tão difícil, é compensada pela solidariedade do grupo doméstico. Em vez de se desagregar, a família ganha uma nova força e o sentimento de identificação ao grupo vai ser maior. Nesta fase há uma profissionalização, para os homens, e/ou uma centralização do universo da mulher na família. No terceiro momento, a família passa a morar na Zona Norte e/ou volta para o Rio Grande do Norte e, em seguida, vai morar em uma "casa própria" ou "de conjunto", adquirindo o seu próprio imóvel. Geralmente, então, observa-se uma instalação definitiva ou uma estada prolongada na Zona Norte. A migração, nos relatos dos interlocutores que moraram fora do Estado, é sempre apresentada como temporária, mesmo se, de fato, não voltaram mais a morar no seu local de nascimento.

A ligação com o lugar de origem existe e passa pela solidariedade da família, dos vizinhos e dos compadres, mas também pela referência a uma história e a uma cultura comuns. Quando são pessoas que não se integraram ao novo contexto urbano e à vida nos conjuntos habitacionais, este lugar é sempre lembrado com saudade. Parece que o sentimento de identificação com o grupo de origem desaparece quando se tratam de filhos dos migrantes ou no caso de migrações satisfatórias. Acontece, nestes casos, uma identificação com o novo local de vida e uma reapropriação do espaço, através da negação das suas raízes: eles não são mais migrantes, mas sim moradores da Zona Norte. Com a negação da origem, nota-se pouca referência ao corpus 
narrativo tradicional. Os romances de cordel e as estórias de trancoso cedem o lugar para outras narrativas e novas poesias, que correspondem melhor ao novo quadro geográfico, social e econômico no qual o indivíduo passa a morar. Se as trajetórias de vida representam uma homogeneidade temática e formal, revelando uma tentativa de distanciamento de um passado rural, outros discursos podem ser analisados como tentativa para legitimar uma presença num novo local de morada. Assim, veremos a seguir como os novos moradores 'bricolam' suas referências culturais, recontando estórias, lembrando e criando fatos e casos, enfim, adaptando as narrativas tradicionais a um novo modo de vida.

\section{AS HISTÓRIAS DA ZONA NORTE}

Coletamos, principalmente, dois tipos de textos que podem ser considerados como criações originais e que dizem respeito à construção de uma nova identidade local. De um lado, encontramse as descrições do passado de Igapó, misturadas às histórias de vida, quando a Zona Norte não existia ainda e o vilarejo tinha todas as características de uma cidade do interior. De outro lado, temos uma explicação de por quê Igapó não se desenvolveu e não conseguiu se beneficiar do progresso que existe hoje na Zona Norte. Nos dois tipos de textos, temos exemplos da intromissão do imaginário junto ao real, ao passado e ao presente ${ }^{24}$.

\section{Igapó e o início da Zona Norte}

É interessante voltar aos textos originais para entender a visão do passado e também da Zona Norte. Assim, Seu Xixi ${ }^{25}$, designado pela comunidade como o detentor da memória de Igapó, apresenta a história da Zona Norte nos seguintes termos:

"Igapó era a tribo, quando os holandeses vieram eles játinham desaparecido. Só Felipe Camarão expulsou com a esposa Clara e Henrique Dimas e outros também. Ele (Felipe Camarão) já estava manso e recebeu dois títulos porque nasceu aqui em Igapó, só não tem quem diga onde ele morava. Eu sei que ele era o chefe dos potiguares, a tribo do Rio Grande do Norte, eles moravam à beira do Rio Potengi. Depois ele foi agraciado com o título de Dom Antônio Felipe Camarão pelo rei da Espanha, D. Henrique. O Brasil primeiro foi colônia da Espanha durante sessenta anos, quem descobriu o Brasil foi Portugal ... ele era mandado pela Espanha e o rei deu o título a sua mulher também, Clara Camarão. Quando D. Pedro voltou 
da guerra vencedor, separou tudo da Espanha, aí o Brasil passou a ser sob as Leis de Portugal quarenta anos, o Brasil foi colônia durante cem anos atéa independência. (...) Eu tinha essas história todinha, quem fez foi Dona Fefita e não me lembro bem, tá tudo no caderno, uns documentos com tudo das terras. Mas o nome dela era Maria Bezerra Cavalcante, era dona das terras todinha, ela doou para a Igreja, mas a Igreja não tem nada porque se apossaram de tudo. Pois bem, D. Maria da Cruz, ela foi a primeira professora, ela dava caderno, livro e dava até merenda se trabalhar na prefeitura."

É interessante notar que há uma espécie de concatenação dos episódios históricos, 'esmagando' quatro séculos em alguns anos. A impressão que se tem, depois da leitura desta história, revisitada por Seu Xixi, é que as 'fundadoras' de Igapó, Dona Cruizinha ${ }^{26}$ e Dona Fefita, que são também as historiadoras, viveram na época dos índios potiguares e sob a ocupação holandesa. Da mesma forma, a ligação que o nosso contador da história local faz com a da colonização do Brasil coloca Igapó em um primeiro plano na fundação de Natal, e talvez na descoberta do Brasil! Assim, Seu Xixi cita as fontes da história oficial, mesmo com algumas imprecisões em relação à presença dos índios potiguares e às datas, lembrando a atuação, relativamente recente, das grandes figuras de Igapó: os "donos das terras". Vê-se, então, através desta versão pessoal do passado de Igapó, que a história precisa ser retrabalhada, atualizada e personalizada com nomes e lugares familiares, para poder ser aceita como "a versão" legítima da história de Igapó. A introdução do locutor na história é um recurso clássico da tradição oral como prova da veracidade dos fatos.

Em uma outra entrevista Seu Xixi sublinha:

"A tribo era aqui em Igapó, os holandeses ficaram na Cidade Alta (no Forte) e moravam em Extremoze fizeram uma Igreja que tinha um túnel (que vinha de Extremoz até o Forte e havia uma fortuna)".

Essa versão resumida do passado colonial, colocando Igapó no centro dos eventos históricos, foi encontrada várias vezes ao longo da pesquisa, com algumas variantes de nacionalidade dos colonizadores (franceses, ingleses, americanos). Os holandeses, ou outros estrangeiros, parecem tomar o papel dos Portugueses na colonização do espaço: foram eles que descobriram, exploraram e levaram as riquezas para fora do Brasil. De uma forma ímpar, mas dentro de uma mesma lógica, os "estrangeiros" e, particularmente, os holandeses, aparecem como os personagens que deixaram os marcos históricos no Nordeste (Mello 1986:29-30). O Forte dos Reis Magos, uma igreja em Extremoz, de onde tirava-se toda a riqueza da região (ouro), capelas, minas, cadeias e outros 
monumentos históricos, contendo construções subterrâneas, remetem à existência de mundos sobrenaturais, adormecidos, povoados por seres misteriosos, animais e espíritos, descrevendo uma representação do passado bastante original ${ }^{27}$.

A referência às aparições misteriosas ou demoníacas é freqüente nas histórias de cordel ou na tradição oral, geralmente consideradas como ficções ${ }^{28}$. Nelas, encontra-se uma descrição fiel dos seres sobrenaturais (as almas) e, sobretudo, dos chamados Reinos Encantados. Os lugares não habitados e situados no "mato" ou nas montanhas são carregados de mistérios e de aparições: animais ou monstros que defendem uma bela princesa presa nas entranhas da terra ou numa lagoa. A esses seres sobrenaturais vêm juntar-se outros monstros, diabos e espíritos que moram no universo das forças negativas e perigosas, integrando o sistema de representações das forças sobrenaturais e, portanto, seguindo uma mesma lógica. Geralmente, as aparições recebem o nome genérico de almas, que é válido para todos os fenômenos estranhos. Estes espíritos podem ter ações benéficas ou maléficas, porque tanto podem atormentar os vivos como podem prestar serviços, sob a condição de que se reze para o seu descanso eterno. Essa bivalência corresponde aos diferentes aspectos nos quais as almas podem aparecer e às condições requisitadas para suas aparições: na noite, nas sombras, nos sonhos e/ou nos lugares não habitados. Se os espíritos dos mortos - humanos ou animais - aparecem na forma de pássaros noturnos e surgem das trevas, eles também emergem nos sonhos dos vivos. Neste caso, as almas - espíritos dos ancestrais ou dos antigos moradores do lugar - não são muito perigosas e pedem uma comida espiritual: algumas rezas. Essas almas vagando, procurando o descanso eterno, são muitas vezes parentes, identificados como tais em virtude de se mostrarem sob uma aparência humana. Graças às suas aparições fugidias, a seus passos pesados, às suas mortalhas brancas e aos seus gemidos, são facilmente perceptíveis. As almas acordam os vivos, chamando-os pelo nome, batendo na porta, fazendo barulho etc. A bivalência do mundo dos mortos, que se revela às vezes positiva e às vezes negativa, é reforçada pelo caráter humano e animal das aparições; sua indeterminação é acentuada pelo fato de que as almas e os outros seres sobrenaturais parecem estar agrupados em um mesmo lugar natural. Neste caso, não são mais mortos familiares, mas ancestrais estrangeiros ao grupo familiar ou de residência que aparecem fora dos lugares habitados. Esta representação animal dos espíritos corresponde, em parte, às caiporas, espíritos de ancestrais indígenas e, portanto, personagem autóctone morando nas florestas e nas montanhas. Estes seres são descritos como sendo almas penadas ou triksters (espírito gozador e cruel) e podem ser consideradas como uma 
manifestação ambígua da potência do universo sobrenatural no mundo selvagem. Da mesma forma, as almas penadas e os santos aparecem, regularmente, nesta natureza muito habitada pelos seres sobrenaturais. Enfim, as montanhas e as pedras, perto da moradia das caiporas, são também os lugares onde estão escondidos os tesouros, onde estão presas princesas encantadas, os monstros ferozes, os humanos transformados em serpentes ou em animais mágicos.

Os reinos encantados também estão presentes nos romances de cordel. São lugares sobrenaturais adormecidos, povoados por seres fantásticos, com poderes limitados; eles são fechados e invisíveis ao olho humano sem experiência. Eles representariam mundos desaparecidos ou se encontrando no estado de natureza. São opostos às manifestações divinas ou malignas (santos, diabos, monstros etc.) ou, então, às dos espíritos dos mortos que vagam na face da terra (caiporas, almas) $^{29}$. No final da análise, os reinados encantados aparecem como lugares intermediários entre o mundo dos ancestrais, o mundo selvagem e o mundo dos homens. Essa descrição serve também para explicar a presença de túneis cavados pelos holandeses; histórias onde o "ocupante-inimigo" teve um papel civilizador primordial. São os holandeses e não os portugueses que aparecem, então, como os desbravadores, portadores da civilização e, ao mesmo tempo, responsáveis pela pilhagem das riquezas do país ${ }^{30}$.

A insistência sobre um elemento - a presença dos ocupantes holandeses - remete-nos a uma representação do passado compartilhada pelos moradores, como também faz referência a um mundo sobrenatural presente nos monumentos históricos.

\section{Glória e decadência de Igapó, ou a maldição de Frei Damião}

Depois da referência à origem de Igapó e à história oficial, Seu Xixi continua descrevendo o lugar com a presença americana, 'pulando' alguns séculos. Em 1940-45, no período da segunda Guerra Mundial, moravam americanos em Igapó; eles fizeram um campo de pouso que desapareceu depois da Guerra e só deixaram a base de Parnamirim. Seu Xixi lembra-se que, em 1950, todos os habitantes de Igapó trabalhavam no centro de Natal e iam para a feira do Alecrim a pé. O trem saía

de manhã e só voltava à noite. No Alecrim existia um bonde até as Rocas. As oficinas tinham saído do bairro e a Ponte de Ferro "tinha mão e contramão"31. A linha de trem ia até a margem do rio, onde havia uma estação; depois, passava-se para uma canoa, que descia no bairro do 'Passo da Pátria'. Naquela época, Igapó só tinha uma rua, a Siqueira Campos, até o Km 8, lugar chamado 
Galo. Segundo Seu Xixi, "até a Redinha e até o Gancho era tudo mato"32.

Todos os nossos interlocutores insistem em dizer que, quando eles chegaram na Zona Norte, "não tinha nada" ou "era tudo mato". O "antes", que pode designar um passado longínquo e indefinido como a data de chegada na Zona Norte, reforça a idéia de que o passado é trabalhado. Israel, um antigo morador, fez um tour em Igapó para lembrar a sua vida ${ }^{33}$. Como Seu Xixi, ele vai escolher como marco histórico a presença dos americanos e toma as mesmas referências espaciais: 'monumentos' que organizam uma representação comum do passado e do espaço.

"Aqui morava minha primeira namorada. Aqui era mata (no conjunto Igapó) e a COHAB construiu o primeiro conjunto, que deu o nome de Igapó, e era vizinho a minha casa que eu me criei. Com seis anos, depois da Guerra de 45, viemos de Natal fugindo da guerra, nós recebemos umas ameaças, nós morávamos pertinho dos fuzileiros navais e lá teve um tiroteio que deixou todo mundo tenso e aqueles carros blindados passaram do Alecrim para as Quintas e a ponte de Igapó ficou interditada. $\mathrm{Na}$ antiga ponte, que não passava carro nessa época, e os soldados estavam com medo de bombardear a ponte e terminou com a passagem de um Zepelim que passou muito baixo e agitou o bairro que era o campo do Riz. Papai trabalhava no curtume de J ota Mota, que era em frente à base naval, só que começou com o couro salgado e depois tirava o sal e botava casca de mangue ... e fazia a sola de sapato e quando teve esse problema papai já sabia que ia trabalhar na rede ferroviária e eu vi a construção dos conjuntos em 1968/69 aqui em lgapó."

Vê-se, então, que esta representação do espaço é comum a todos os moradores antigos da Zona Norte: antes, no momento em que eles chegaram, não tinha nada, era só "mato", sem ter os sinais do progresso que são visíveis hoje (eletricidade, saneamento básico, transporte, estradas, a ponte - velha e nova - , comércio etc.). Progresso que chegou depois dos americanos. Parece que todos os entrevistados foram os desbravadores da Zona Norte e participaram da sua construção.

Depois, nossos historiadores fazem referência a uma época mais recente, que corresponde mais ou menos à expansão da Zona Norte e à construção acelerada dos conjuntos habitacionais, em torno dos anos 70. A Zona Norte começa a parecer como existe hoje. Todos lembram o papel dos políticos, mas também de um padre belga, Pe. Thiago, que acompanhou esta fase (1969/70) e até hoje celebra missas em alguns bairros da Zona Norte. Segundo eles, o padre trouxe muitos benefícios para a comunidade: construção de escolas, creches, centros comunitários, animação de grupos de jovens etc. Para se lembrarem da época da construção das obras, fazem referências históricas particulares: presença dos americanos, governo de tal político, mudança de grande porte no bairro (construção ou reconstrução da ponte), evento marcante na vida pessoal, chegada 
na Zona Norte, primeiro emprego etc. Seu Xixi, por exemplo, toma como referências temporais os diferentes governos. Assim, o primeiro conjunto habitacional a ser construído foi o Conjunto Igapó, durante o governo de Lavoisier Maia, em 1963. Durante o governo de Monsenhor Walfredo Gurgel, em 1965, foi feita a ponte de cimento armado e foram loteados os terrenos da Zona Norte. O conjunto Amarante foi construído depois da instalação das fábricas Sparta, Seridó, Incarton. Estas fábricas da indústria têxtil foram construídas depois de 1982 e fecharam as portas oito anos após. Sem lembrar exatamente a data, ele faz ainda referência a um evento político importante. Assim, a fábrica Sparta abriu na época em que o mandato do deputado Aluízio Alves foi cassado, e este mesmo deputado foi quem permitiu a construção das fábricas, pois era seu sócio majoritário.

Elba $^{34}$, que passou cinco anos no Rio de J aneiro e veio trabalhar nestas fábricas em 1977, até elas fecharem - ela veio morar na Zona Norte só em 1980 - , lembra este tempo dos pioneiros, onde nada era fácil:

“Foi, eu cheguei primeiro [da família] em Igapó, é nessa época, era tudo difícil, né? Tá com dezesseis anos que eu vim morar em Igapó, dezesseis anos atrás o negócio era outro, ônibus era muito difícil, tinha pouco, dois, três só de cada linha, tudo era muito difícil, emprego muito difícil também. Eu, quando comecei a trabalhar na Esparta, por ironia do destino eu morava em Candelária e vinha trabalhar na Esparta, aí depois quando eu vim morar em Igapó passei a trabalhar em Neópolis (...) depois, depois vim morar no Santa Catarina, né? No conjunto novo bonito foi quando eu recebi aqui o conjunto, minha casa no conjunto Santarém, só que quando eu vim morar aqui, coitado do Santarém, nem ônibus tinha, pra pegar ônibus tinha que ir ou pra Santa Catarina ou pra estrada da Redinha. Era, era um sacrifício realmente, era um sacrifício. Eu saía de onze horas do trabalho lá da Alpargatas, chegava em casa meia noite, porque uma hora era pra tá andando a pé, descer lá no Santa Catarina e vir. Era um perigo muito grande, mas também naquela época existiam menos marginais, né? É, e quer dizer, não é que existisse menos, é que eles ainda eram novinho (...) mas hoje em dia não, hoje em dia a Zona Norte tá ótima. Nossa! É uma beleza! Tem tudo, tem banco, tem ... tem os melhores supermercados, tem ônibus, nem se fala! Tá bom demais a asa norte, eu mesmo gosto muito daqui."

O que é interessante na descrição de Elba é que ela tem outras referências espaciais e históricas, diferentes das dos nossos historiadores 'oficiais'. A 'origem da Zona Norte' começa a partir do momento em que ela volta do Rio de J aneiro. Lá, Elba aprendeu a profissão de costureira com um "francês", depois de ter começado como operária em um pequeno ateliê que fabricava artigos de couro. Ela conseguiu este primeiro emprego através da ajuda da proprietária da casa onde a família morava. A sua trajetória é interessante porque, através do seu discurso, podemos ver que ganhou uma certa independência, graças à migração e à profissionalização. Conseguiu uma liberdade que 
não tinha quando morava com o seu pai, conseguindo também adquirir uma independência financeira, o que permitiu poder separar-se do marido e trabalhar quando quiser. Hoje, pode "escolher" os dias e o tipo de trabalho: ela tem um ateliê de costura em sua casa, aluga alguns quartos de sua residência para comércio (bar, mercearia, assistência técnica, jogos de vídeo etc.) e trabalha, às vezes, em uma casa de shows, como cozinheira, ou em uma fábrica, por um tempo maior - o que é fácil, com a sua experiência - quando precisa de dinheiro. Se para ela a profissionalização é um sinal de libertação, também é um marcador temporal, porque se refere sempre àquele tempo em que trabalhava em determinada fábrica. Porém, esta visão positiva da Zona Norte não é partilhada por todos. Alguns acham que a Zona Norte e, sobretudo, Igapó, não se beneficia dos progressos da modernidade como deveria. Isto, geralmente, é atribuído a um fato sobrenatural.

Para explicar por que Igapó ficou com os traços de uma cidade de interior, alguns dos nossos interlocutores contam uma história envolvendo a presença de Frei Damião: ele teria vindo pregar na igreja de Igapó, mas como houve muita confusão ("bagunça”), ele amaldiçoou a Praça de Igapó. É Dona Maria de Baia ${ }^{35}$ que apresenta a versão mais completa:

“Frei Damião se hospedava na casa de dona Cruizinha ${ }^{36}$, passava oito dias... quinze, aí depois houve uma briga com uma pessoa, um senhor que já faleceu, mas a filha dele ainda existe... houve uma briga que ela não sabe por que e aí Frei Damião disse:

- Enquanto eu existir, dentro de Igapó não pisarei. Quando eu chegar aí em Igapó é que eu estou perto de morrer, Igapó vai terminar no pó (...) e justamente... Igapó nunca irá pra frente, pra lá vai crescer, aqui dentro não.

De fato você vê. Porque o que é que tem aqui na praça? Não tem um armarinho, não tem uma padaria, não tem uma farmácia, e o que bote vai pra baixo... tudo que inventam botar, vai desce. Você vê essa praça ... tudo bacana ... aí o pó, é o pó mesmo (...). Eu sei que ele disse essa palavra ... que 'dentro de lgapó ele não pisaria nunca mais, ele não pisaria dentro de lgapó e lgapó ia terminar no pó', tudo quanto botasse aqui não ia pra frente, só ia crescer pra lá, pra cá não. Você vê que aqui não tem... essas casas, aqui essas casas são tudo própria, são as mesmas casas, construíram em terreno baldio e nos quintais para os filhos. Aqui a gente paga somente a terra, somente a terra."

Segundo Seu Xixi, este fato aconteceu em 1952 ou 1953. Ele confirma o atraso, mas coloca em dúvida a maldição, porém não a nega radicalmente ${ }^{37}$ :

“(...) foi Frei Damião que disse que a ponte ia cair, foi que inventaram. É tanto que ela não caiu. A outra ponte de ferro, fica até homem e só não serve porque venderam."

Esta explicação é interessante por dois motivos. Primeiro, porque apresenta uma explicação 
do atraso da praça de Igapó e lembra a presença do sobrenatural no universo das narrativas. Sabese que Frei Damião ficou famoso menos pelas suas rezas do que por suas pragas, suas maldições e suas pregações moralizantes. Há muitos 'exemplos', onde gente é transformada em monstro ou animal repugnante, revelando um pecado capital (incesto, roubo, mentira, adultério etc.). Portador de valores da ordem, evangelizando os fiéis através de suas missões 'intensivas', ele conseguiu reunir multidões, inspirando medo e respeito. Uma explicação em termos religiosos, com a intervenção direta do poder divino, através da ação do seu agente privilegiado - Frei Damião - , é um tipo de racionalização que apresenta uma forma disfarçada de resistência dos antigos moradores em defender seu passado e sua história. Também se pode pensar que, se hoje a Zona Norte conhece um desenvolvimento tão grande, e se este não beneficia a todos, então deve existir alguma razão superior - de tipo divino - nesta distribuição desigual de benefícios. Este distanciamento também afasta a fama negativa da Zona Norte, não recaindo desta forma sobre Igapó que, por sua vez, continua a defender os traços característicos de uma pacata cidade de interior, organizada em volta da sua praça e da sua sociabilidade fundada no interconhecimento.

As narrativas da Zona Norte que coletamos mostram como os locutores reinventam a sua história, fazendo referência aos mesmos elementos: datas, personagens, forças sobrenaturais, eventos históricos, marcos da memória etc. são lembrados e reinventados a cada evocação do passado do bairro ou da própria vida. Formalizados ou não numa narrativa, esses elementos terminam formando um conjunto bastante homogêneo que informa sobre a concepção do mundo segundo os locutores.

\section{TRADIÇÃO ORAL E IDENTIDADE NO CONTEXTO URBANO}

Uma pesquisa centrada na vida e nos discursos dos locutores privilegia os temas ligados ao cotidiano dos migrantes, bem como os ligados ao exílio, à partida da terra natal e, às vezes, à possível volta para o lugar de nascimento. Aponta também para a importância da família e da solidariedade, destaca o trabalho como a principal razão da migração. Permite também resgatar um discurso comparativo sobre a vida no lugar de origem e no lugar de destino, a volta para o Nordeste - para os migrantes que se deslocaram para o sul ou outros Estados, fora da região - e, afinal, a instalação e a vida em Natal e na Zona Norte. Porém, as lembranças e o discurso sobre a migração nos levam 
sobretudo ao passado do local; à sua origem como um vilarejo tradicional; à importância dos índios, dos colonizadores (holandeses e franceses), dos antepassados (Dona Cruizinha), das festas passadas (o carnaval, as cheganças, os marujos etc.) e, afinal, à importância dos monumentos na rememoração do passado (a praça de Igapó, a ponte de ferro, a linha do trem, as fábricas etc.). As transformações ocorridas na Zona Norte são destacadas como sinais de progresso; o papel da igreja, dos sindicatos e dos políticos neste processo é lembrado na ocasião. Enfim, chegando no nível das narrativas mais tradicionais, os folhetos, os romances de cordel e as estórias de trancoso sofrem um processo de esquecimento e são, geralmente, denegridos pelos mais jovens, que desconhecem este tipo de literatura que lembra a sua origem. Outras histórias ocupam o seu lugar, retomando elementos existentes na tradição oral, e que, em sua maioria, seguem uma estrutura narrativa similar. Parece que as histórias vão se transformando junto às identidades dos migrantes.

Assim, a dificuldade encontrada em coletar as narrativas, sobretudo escritas, mas também os contos maravilhosos, pode ser explicada pelo fato de que os migrantes, ao chegarem no espaço urbano, esforçam-se em apagar o estigma do camponês. Outras narrativas surgem e, geralmente, o maravilhoso volta, com a presença do tema dos mundos subterrâneos, que é atualizado com a referência à história recente ou a episódios da vida pessoal do locutor.

Finalmente, algumas correspondências podem ser notadas entre o processo narrativo e a descrição da realidade, percebendo-se a lógica de ordenação do mundo que fica em um nível mais profundo. Assim, na realidade como na ficção narrativa, há uma divisão do universo social, bem como uma continuidade entre o mundo dos homens e o sobrenatural. Essa bivalência se reencontra nas formas narrativas, onde há uma impossibilidade em distinguir a realidade da ficção. O mundo sobrenatural onipresente integra-se em uma representação do mundo necessariamente harmônica. Parece que neste momento houve uma acumulação de estórias que foram contadas e recontadas pelos diferentes locutores e poetas. Se a maior parte dos migrantes não faz mais referência à tradição narrativa e oral da sua infância, não quer dizer que a esqueceu. Graças à escritura, à leitura e à rememoração das poesias e das estórias, os migrantes defendem e reatualizam os seus valores culturais.

Os textos que lembram tanto um passado como também um lugar de nascimento são os veículos privilegiados da tradição e da identidade. Porém, na zona urbana, pode-se observar o desaparecimento progressivo das expressões da cultura tradicional, como os dramas, a cura pelas 88 plantas, os rituais e as procissões e, sobretudo, os folhetos de cordel. Para os migrantes, esse 
desaparecimento é acompanhado pela desagregação das relações sociais que existem nas zonas rurais. A organização espacial das cidades e, sobretudo, das periferias, destrói o tipo de sociabilidade tradicional, baseada na família numerosa, no conhecimento mútuo e na vizinhança. Além disso, a identificação dos leitores com os personagens diminui e explica, em parte, a indiferença dos mais jovens. Os filhos dos migrantes se sentem atraídos por outras formas culturais, que são as da cultura urbana. Assim, quando se estuda a história dos folhetos de cordel, o seu modo de transmissão ou mesmo a vida dos poetas, parece que as criações narrativas e poéticas são estrangeiras ao universo urbano e pertencem a uma cultura de migrantes de primeira geração, oriundos das zonas rurais ou continuando a ter fortes ligações com a comunidade de origem (Cavignac 1997b). Longe de ser uma reflexão pessimista sobre o desaparecimento total de uma cultura tradicional, pensamos, ao contrário, que se trata de um fenômeno clássico. É 'natural' observar o desaparecimento do corpus tradicional em um contexto urbano, porém isso não quer dizer que há um desaparecimento absoluto das criações narrativas. Assim, é possível concluir que o grau de adaptação do indivíduo ao seu novo local de vida parece variar com a importância dada às "estórias de antigamente"; quanto mais o migrante é integrado à cidade, menos referência a essas narrativas é encontrada no seu discurso.

No caso dos migrantes que se instalaram na Zona Norte podemos observar, em vez de um simples sumiço da tradição oral, uma proliferação de narrativas, acompanhando-se de uma recuperação da história local. Esses novos textos integram elementos e seguem o modelo das narrativas da literatura oral. Elas continuam oferecendo uma racionalização do mundo social e sobrenatural, passado e presente, inscrevendo as experiências pessoais no tempo contínuo da tradição.

Julie A. Cavignac. Antropóloga, doutora em Etnologia eSociologia Comparativa pela Université de Paris X Nanterre, éprofessoraadjuntado D epartamento de AntropologiadaUniversidadeFederal do Rio Grandedo Norteecoordenadora do grupo de pesquisa Cultura, Ideologiae Representações Sociais(CIRS). 
EVOLUÇÃO DA POPULAÇÃO DA ZONA NORTE 1975-1999

1975

Menos de 40.000 habitantes

Primeiro conjunto habitacional (Conjunto Igapó): 600 habitantes - 116 casas

média de 5,2 moradores por domicílio

1980

40.479 habitantes (menos de $10 \%$ da população de Natal)

1986

60.000 habitantes (estimativa)

1991

146.822 (ou 146.854) habitantes

34 conjuntos - 20.375 domicílios

média de 7,2 moradores por domicílio

15 favelas

? loteamentos populares

Bairro de Igapó : 24.286 habitantes - 5.376 domicílios

média de 4,5 moradores por domicílio

1996

206.115 habitantes - 47.956 domicílios

média de 4,2 moradores por domicílio

16 favelas (17.565 habitantes )

Bairro de Igapó: 25.577 habitantes - 5.958 domicílios

média de 4,2 moradores por domicílio

1999 (estimativas)

250.000 a 300.000 habitantes

44 conjuntos 


\section{NOTAS}

1 Apresentarei aqui alguns resultados de pesquisas que venho desenvolvendo desde 1995 na UFRN.

2 Categoria nativa que designa os contos maravilhosos.

4 O Conjunto Igapó foi um dos primeiros conjuntos habitacionais a serem construídos na Zona Norte, em 1975 (Vidal 1998:54). Contava então com 600 moradores, distribuídos em 116 casas (média de 5,2 pessoas por casa). Em 1991, já tornado bairro e abrigando alguns conjuntos habitacionais, tinha 24.286 moradores, em 5.376 domicílios (média de 4,5 pessoas por casa). Em 1996, contavam-se 25.577 habitantes no bairro, distribuídos em 5.958 casas (média de 4,2 pessoas por casa). Igapó conheceu uma taxa de crescimento de 5,13\% entre 1980 e 1991, enquanto a totalidade da Zona Norte vivia uma explosão imobiliária ( $12,44 \%$ de taxa de crescimento no mesmo período). Esta parte da cidade, em 1991, contava com 34 conjuntos (abrigando 20.375 unidades habitacionais), perto de 15 favelas e vários loteamentos populares (autoconstrução), totalizando uma população de 146.822 habitantes (média de 7,2 pessoas por casa). Em 1996, 206.115 pessoas estavam morando na Zona Norte, que contava com 47.956 domicílios particulares permanentes ocupados (média de 4,2 pessoas por casa). (IBGE, IPLANAT 1996; Vidal 1998).

5 O total dos habitantes da Zona Norte, em 1990, foi de 146.854 moradores; em 1996, 206.115. Mas “moradores residindo em domicílios coletivos e improvisados" não foram contabilizados. Hoje, sem um levantamento oficial e fiel, acredita-se que o número de moradores da Zona Norte se aproxime dos 300.000 (Diário de Natal, 12/09/99).

6 Alain Morice (1993:356), que estuda os migrantes trabalhando na construção civil em Santa Rita, cidade vizinha a J oão Pessoa (PB), também nota a existência da categoria "trabalhador agrícola-pedreiro".

7 Sobre este assunto ver Cavignac 1997b.

8 Muitos elementos apresentados aqui são sistematizados em Langdon 1999.

9 Limitar-nos-emo a esclarecer a questão da tradição oral como possível suporte de uma memória coletiva e não da memória em geral. Sobre este assunto ver Candau 1998.

10 Do tupi poti'war. comedor de camarão. 'Potiguar' é o termo genérico que designa os habitantes do Rio Grande do Norte.

11 Já que para Lévi-Strauss não há diferença de natureza entre o conto e o mito, pode-se incluir este último no quadro da tradição oral das populações interioranas do Nordeste. Os pesquisadores, para realizar a análise deste corpus narrativo, devem recorrer à história oral, à teoria da literatura, à linguística, à semiótica etc. Para mais detalhes, cf. Cavignac, 1997a:192-203. No decorrer deste texto, farei referências a outros estudos.

12 Penso, particularmente, nos trabalhos de Maria Isaura Pereira de Queiroz.

13 Apesar do que Luís da Câmara Cascudo, na sua obra "Literatura oral”, propõe uma sistematização do estudo (1978).

14 Pode-se reconhecer a Luís da Câmara Cascudo (1952) a tentativa de uma tal perspectiva.

15 O método de Propp inspirou outros estudos sobre os contos, sobretudo os que tratam da literatura oral e da mitologia africana (Paulme 1976; Griaule e Dierterlen 1965) e até mesmo estudos sobre o cordel (Slater 1984).

16 História com $\mathrm{H}$ maiúsculo designa a disciplina, ao passo que a história com $\mathrm{h}$ minúsculo entendo como referindose à oralidade.

17 Ver uma discussão mais detalhada em Cavignac 1997b:208-213.

18 Cf. Idelette Muzart-Fonseca dos Santos in Bernd e Migozzi (1995).

19 Para o estudo dos folhetos de cordel, de um ponto de vista sociológico ou histórico, podemos lembrar os legados importantes de Arantes (1982), Menezes (1977), Slater (1984), Terra (1983) e Santos (Idelette 1997).

20 Cf. o relatório da pesquisa financiada pelo CNPq realizada entre 1994 e 1996.

21 Na pesquisa, feita entre 1994 e 1996, 25 pessoas foram entrevistadas (a grande maioria delas morando em conjuntos 
habitacionais). Tentamos coletar o testemunho de vários membros de um grupo familiar, junto com a memória dos folhetos de cordel, narrativas orais, apontamentos sobre a história da Zona Norte etc. Em uma segunda fase da pesquisa (1997/99), seis pessoas a mais foram entrevistadas (desta vez, só mulheres, com idade acima de 50 anos), além de um trabalho realizado na Escola Municipal Potiguaçu e vários contatos mantidos com os antigos entrevistados.

22 Incluindo os parentes próximos ou mais distantes, a sociabilidade estende-se aos antigos vizinhos, aos amigos ou às pessoas com quem se estabelece uma ligação qualquer (compadre, patrão, colega etc.).

23 Muitos romances de cordel e estórias de Trancoso apresentam o motivo narrativo do exílio, inserido em uma aventura romanesca que, geralmente, tem um final feliz (cf. Cavignac 1996).

24 Coletamos poesias criadas pelos entrevistados, que não são poetas profissionais, com uma exceção: o poetavioleiro Raimundo Galdino.

25 Seu Xixi nasceu em Estivas, em 1925, perto do município de Extremoz, que faz fronteira com a Zona Norte de Natal. Cinco anos depois a sua família foi morar em Extremoz. O seu pai morreu quando tinha oito anos e, a partir daí, começou a trabalhar "na enxada e de barro". Não foi para escola, mas sabe ler e escrever, porque teve que sustentar toda a família (eram sete filhos) e tem orgulho de dizer que nenhum deles morreu. Em 1936 foi morar em Touros, onde trabalhava na prefeitura e morava seu avô materno. Chegou na Zona Norte em 1950, onde tinha um irmão morando, com trinta e três anos; casou-se com uma moça de Igapó tendo, dessa união, nove filhos. Começou trabalhando como servente da prefeitura mas, em 1954, foi trabalhar em Belém do Pará, em uma granja, com um outro irmão. Um ano depois voltou e começou de novo a trabalhar na prefeitura. Em 1962, Seu Xixi torna-se sócio do Círculo de Trabalhadores Cristãos de Igapó e em 1968 é eleito presidente deste mesmo Círculo, que tem como principal objetivo a assistência dos seus sócios. O primeiro Círculo Operário de Trabalhadores Cristãos tinha sede no bairro das Quintas, atendendo a população até a Redinha. Foi fundado pelo Padre Augusto Bretão em 19/10/56. Prestava assistência médica e odontológica através de estagiários. Sua segunda sede foi instalada na Escola Potiguaçu, durante o governo de Sílvio Pedrosa. Hoje Seu Xixi é uma figura de renome na praça de Igapó: homem público, detentor da memória do local, chegou a candidatar-se a vereador.

26 Dona Cruizinha morava em Igapó nos anos 50.

27 A pesquisa atual "Imagens da Colonização" desenvolve esses temas (cf. Cavignac 1999).

28 Coletamos algumas narrativas contando casos de botijas, aparições de almas e assombrações, em particular as estórias contadas por Israel e Dona Eva.

29 Seu Nazareno Patrício faz referência à Besta Fera: "Era, era o cavalo do Cão e dizia que o nome era .. tinha o cavalo do cão, era voando, e por terra é a Besta Fera, dava o nome de Besta Fera (...) aí hoje tá aí tudo servindo de transporte, não existe nada disso (...) ainda tinha até um número da Besta Fera, era ela vinha com um número, era 7766 (...) quando se viu o cavalo do Cão ou a Besta Fera com esse número aí pode ficar que era a besta fera já tava perto do mundo se acabar mesmo(...)".

30 Evaldo Cabral de Mello (1986:25-65) aproxima a insistência nas lembranças da atuação dos holandeses ao movimento nativista dos séculos XVIII e XIX.

31 Para Seu Xixi foram os franceses que construíram a ponte de ferro, outros afirmam que foram os holandeses que teriam construído também, além da ponte, algumas casas de pedra. A ponte, erguida pelos ingleses, foi terminada em 1916 e foi construída uma nova durante o governo Walfredo Gurgel (1966/70), que foi duplicada pelo governador Geraldo Melo (1986/90) (Tribuna do Norte 21/06/92).

32 Sílvio Pedrosa fez a estrada de Igapó em 1955, quando Dix-Sept Rosado era governador, segundo Seu Xixi.

33 Israel nasceu no município de J oão Câmara (RN), em 1939, e veio para Natal em 1944 morar com seus avós matemos (a sua família paterna é da Paraíba, de Bananeiras). Ele passou a morar na Zona Norte em 1946, onde seu pai era condutor de trem e migrou várias vezes (1960: Minas Gerais; 1961: São Paulo). Ele voltou para Natal em 1963 (mudou várias vezes e passou um ano em Montanhas, trabalhando na agricultura). Em 1968, ele se estabeleceu definitivamente na Zona Norte. Teve vários empregos (pintor, segurança, eletricista, pedreiro, motorista, agricultor etc.) e tem 'dons' 
artísticos (cantor de coral, músico, mamulengueiro, folião de carnaval).

34 Elba nasceu em 1950, em Reduto, pequena cidade perto de São Bento do Norte (RN). Seus pais vieram com ela em 1962 para Natal, cidade onde eles já tinham parentes. A sua irmã, Eva, foi para o Rio de J aneiro (1970), acompanhando o esposo e o irmão mais velho. Dois anos depois, Elba também foi para lá e voltou em 1977, sabendo costurar. A família decidiu retornar para o Rio Grande do Norte e só um irmão continuou morando no Rio de J aneiro. Todos foram morar na Zona Norte em 1982 e, hoje, moram em conjuntos habitacionais, pouco distantes uns dos outros. Os pais vivem cada um na casa de um filho: o pai em Parnamirim (município vizinho a Natal) e a mãe em Touros, onde uma parte da família continua morando.

35 Alisete do Nascimento ou Dona Maria de Baia nasceu em Natal, em 1929, mas chegou à praça de Igapó aos cinco anos de idade, em 1934. Ela trabalha desde os 44 anos como atendente de enfermagem. Na sua juventude, ela foi estudar em Recife (PE) durante um ano e quatro meses a convite de uma irmã que morava lá. Quando os pais adoeceram, ela parou de estudar e começou a lavar roupa para ajudá-los. Também é parteira, pois com a ajuda de Padre Thiago, de quem ela era atendente no Círculo Operário, conseguiu fazer um curso de parteira, apesar de já exercer o ofício antes disso. Casou-se duas vezes, tendo seis filhos de cada união. O seu marido trabalha em J oão Câmara como vaqueiro e só vem a Natal a cada quinze dias. A família de dona Maria está toda espalhada pelos municípios do Rio Grande do Norte e São Paulo. Mesmo Dona Maria de Baia não sendo uma migrante, seus pais (São J osé do Mipibú), seu marido (J oão Câmara) e seus filhos (São Gonçalo do Amarante e São Paulo) conhecem a situação.

36 Uma das fundadoras de Igapó.

37 Pode ser que Seu Xixi, participando ativamente das atividades da Igreja, tenha se deixado convencer pelo padre de que não deve negar esta explicação. Também, tendo estatuto a defender, ele não deve prestar atenção a este tipo de discurso "atrasado". 


\section{REFERÊNCIAS BIBLIOGRÁFICAS}

AGIER, Michel.1995. “Mobilidades: Algumas Formas Recentes de Diferenciação Social”. In: M. Agier (org.), Imagens e identidades do trabalho. São Paulo: Hucitec.

AJ ARA, César (org.). 1993. “Dynamiques du Territoire: La População et les Activités Économiques”. Problèmes d'Amérique Latine, 9:45-72

ARANTES, Antônio Augusto. 1982. O trabalho e a fala. Estudo antropológico sobre os folhetos de cordel. São Paulo: Kairos/Funicamp.

BAUMAN, Richard. 1975. “Verbal Art as a Performance”. American Anthropologist 77: $290-311$.

BELMONT, Nicole. 1970. “Les Croyances Populaires comme Récit Mythologique”. L’Homme X(2): 94-108.

BELMONT, Nicole. 1986. Paroles Païennes. Mythe et Folklore. Des frères Grimm à Pierre Saint Yves. Paris: Imago.

BERND, Zilá; MIGOZZI, J acques (orgs.). 1995. Frontières du Littéraire, Littératures orale et populaire Brésil/ France. Limoges: PUL.

BOUVIER, J ean Claude. 1987. “Contes de L'Écrit, Contes de L'Oral : L'Opposition est-elle Pertinente?" In: Littérature orale traditionnelle - Actes du Colloque (20-22 novembre 1986). Paris: Fondation Calouste Goulbenkian:317-330.

BOUVIER, J ean Claude. 1992. “La Notion d'Ethno-texte”. In: J .N. Pelen e C. Martel (orgs.), Les Voies de la Parole. Aix-en-Provence: Université de Provence: 12-21.

BOYER, Pascal. 1982. “Récit Épique et Tradition”. L’Homme XXII(2): 5-34.

. 1988. Barricades Mystérieuses et Pièges à Pensée. Introduction à l'Analyse des Épopées Fang. Paris: Société d'Ethnologie.

CABANES, Robert. 1995. “Hommes et Femmes entre Culture d’Entreprise et Culture Ouvrière. Un Exemple Brésilien”. In: R. Cabanes (org.), Salariés et entreprises dans les pays du sud. Contribution à une Anthropologie Politique. Paris: Karthala.

CANDAU, J oel. 1998. Mémoire et Identité. Paris: PUF.

CASCUDO, Luís da Câmara. 1978. Literatura oral no Brasil. (2.ed.) Rio de J aneiro: J osé Olímpio. . 1986. Contos Tradicionais do Brasil. Belo Horizonte/São Paulo: Itatiana/USP.

CAVIGNAC, J ulie. 1994. Mémoires au Quotidien. Histoire et Récits du Sertão du RN. (Brésil). Tese de doutorado, Université de Paris $X$, Nanterre. . 1997a. "Romances d'Exil: Littérature de Cordel et Migrations au Brésil”. Autre Part 1: 15-39. 1997b. La Littérature de Colportage au Nord-est du Brésil: De l'Histoire Écrite au Récit Oral. Paris: Ed. du CNRS, coll. Pays iberiques/Amerique.

. 1997c. Memórias de Migrantes. Pesquisa Etno-literária de uma Comunidade da Zona Norte da Cidade de Natal. Relatório final de pesquisa. Natal: UFRN-CNPq. 
1999. “Vozes da Tradição: Reflexões Preliminares sobre o Tratamento do Texto Narrativo em Antropologia. Horizontes antropológicos. Porto Alegre: UFRGS.

CLEMENTINO, Maria do Livramento. 1995. Economia e Urbanização: O Rio Grande do Norte nos Anos 70. Natal: UFRN/CCHLA.

DETIENNE, Marcel. 1979. “Repenser la Mythologie”. In: M. Izard et P. Smith. La fonction symbolique. Essais d'Anthropologie. Paris: Gallimard.

DOIMO, Ana Maria. 1995. A veze a Voz do Popular: Movimentos Sociais e Participação Política no Brasil pós70. Rio de J aneiro: Relume Dumará/ANPOCS.

DURHAM, Eunice Ribeiro. 1984. A Caminho da Cidade: A Vida Rural e a Migração para São Paulo. (3.ed.) São Paulo: Perspectiva.

. 1986. “A Sociedade Vista da Periferia”. RBCS 1(1):84-99.

DURKHEIM, Émile. 1985. Les Formes Élémentaires de la Vie Religieuse. Le Système Totémique en Australie. (2e.ed.) Paris: PUF.

GOODY, J ack. 1977. “Mémoire et Apprentissage dans les Société avec ou sans Écriture: La Transmission du Bagre". L'Homme, XVII(1):29-52.

. 1979. La Raison Graphique. La Domestication de la Pensée Sauvage. Paris: Ed. de Minuit.

GRUZINSKI, Serge. 1988. La Colonisation de L'Imaginaire. Sociétés Indigènes et Occidentalisation dans le Mexique Espagnol XVIºXVIIle Siècle. Paris: Gallimard.

GRUZINSKI, Serge e BERNAND, Carmen. 1990, 1993. L'histoire du Nouveau Monde. Paris: Fayard (vol. I e II). HALBWACHS, Maurice. 1990. A Memória Coletiva. São Paulo: Editora Revista dos Tribunais.

LANGDON, Ester J ean. 1999. “A Fixação da Narrativa: Do Mito para a Prática da Literatura Oral”. Horizontes Antropológicos 12:13-36.

LANNA, Marcos. P. D. 1995. A Dívida Divina: Troca e Patronagem no Nordeste Brasileiro. Campinas: Unicamp.

LE GOFF, J acques. 1996. História e Memória. (4.ed.) Campinas: Unicamp.

LÉVI-STRAUSS, Claude. 1974. Anthropologie Structurale. Paris: Plon (réed.).

MAGNANI, J osé Guilherme. 1996. “Quando o Campo é a Cidade: Fazendo Antropologia na Metrópole”. In: J .G. Magnani e L.L. Torres (orgs.), Na Metrópole: Textos de Antropologia. São Paulo: Edusp/Fapesp.

MATTOSO, Kátia; SANTOS, Idelette M. Fonseca; ROLLAND, Denis (orgs.). 1999. Matériaux pour une Histoire Culturelle du Brésil. Objets, Voix et Mémoires. Paris: L'Harmattan.

MELLO, Evaldo Cabral. 1986. Rubro Veio. O Imaginário da Restauração Pernambucana. Rio de J aneiro: Nova Fronteira.

MELLO, J osé Antônio Gonçalves. 1979. Tempo dos Flamengos. Influência da Ocupação Holandesa na Vida e na Cultura do Norte do Brasil. (2.ed.) Recife: BNB.

MENEZES, Eduardo Diathay Bezerra. 1977. "Para uma Leitura Sociológica da Literatura de Cordel". RBCS VIII(1- 2). 
MENEZES, Marilda Aparecida (org.). 1992. Histórias de Migrantes. São Paulo: Loyola.

MORICE, Alain. 1993. “Une Légende à Revoir : L'Ouvrier du Bâtiment Brésilien dans Feu ni Lieu”. Cahiers des Sciences Humaines 29(2-3):349-371.

. 1999. Em Demanda da Poética Popular: Ariano Suassuna e o Movimento Armorial. Campinas: Unicamp.

PRICE, Richard. 1983. First Time: The historical Vision of an Afro-American People. Baltimore: The J ohns Hopkins University Press.

PRICE, Richard. 1998. The Convict and the Colonel. Boston: Beacon Press Books.

PROPP, Vladimir J . A. 1965. Morphologie du Conte. Paris: Seuil (réed.). . 1983. Les Racines Historiques du Conte Merveilleux. (2e.ed.) Paris: Gallimard.

RIGAMONTE, Rosani Cristina. 1996. “Severinos, J anuários e Raimundos”. In: J .G. Magnani e L.L. Torres (orgs.), Na Metrópole: Textos de Antropologia. São Paulo: Edusp/Fapesp. pp. 233-251.

SANTOS, Hilton. 1978. Pobreza Urbana São Paulo-Recife. São Paulo/Recife: Hucitec/UFPE-CNPq.

SANTOS, Idelette Muzart-Fonseca. 1997. La Littérature de Cordel au Brésil. Mémoire des Voix, Grenier d'Histoires. Paris: L'Harmattan.

SARTI, C. 1995. "São os Migrantes Tradicionais?". Travessia 23:11-13.

SIGAUD, Lygia. 1993. “Des Plantations aux Villes: Ambiguités d'un Choix". Études Rurales 131-132: 19-37.

SLATER, Candance.1984. A Vida no Barbante: A Literatura de Cordel no Brasil. Rio de J aneiro: Civilização Brasileira.

TEDLOCK, Dennis. 1971. “On the Translation of Style in Oral Narrative". J ournal of American Folklore 84:114133.

. 1983. The Spoken Word and the Work of Interpretation. Philadelphia: University of Pennsylvania Press.

. 1988. "The Witches Were Saved. A Zuni Origin Story". J ournal of American Folklore 101:312-320.

TERRA, Ruth Brito Lemos. 1983. Memória de Lutas: Literatura de Folhetos no Nordeste, 1893-1930. São Paulo: Global.

VIDAL, Ademar. 1950. Lendas e Superstições: Contos Populares Brasileiros. Rio deJ aneiro: Gráfica O Cruzeiro.

ZUMTHOR, Paul. 1980. L'Écriture et la Voix. Littératures Populaires, du Dit à l'Écrit. Critique 394:228-239. . 1982. De l'Oralité à la Littérature de Colportage. L'Écrit du Temps 1:129-140. Paris: Ed. de Minuit. . 1997. Introdução à Poesia Oral. São Paulo: Hucitec. 
RESUMO

Este artigo apresenta os resultados de uma pesquisa que vem sendo desenvolvida desde 1995 sobre a memória e as produções narrativas de migrantes oriundos do interior do Rio Grande do Norte, atualmente residindo na Zona Norte da capital do Estado, Natal. O texto apresenta inicialmente o processo de formação da Zona Norte e os fenômenos migratórios existentes na região, para em seguida analisar as histórias contadas pelos migrantes. Se o corpus narrativo tradicional tende a desaparecer no contexto urbano, novas temáticas surgem. Assim, por meio da análise das produções narrativas dos migrantes, é possível avaliar as transformações da cultura 'tradicional'. O artigo procura mostrar que a importância dada às chamadas "histórias de antigamente" e as referências a essas narrativas encontradas no discurso dependem da situação das pessoas no novo local de vida.

\section{ABSTRACT}

This article presents the results of a research that has been conducted since 1995 about memory and narrative production of migrants from the backlands of Rio Grande do Norte state now established in the state capital Natal, more specifically in the northern part of the city, the "Zona Norte". The text initially presents the process of Zona Norte formation and the migratory phenomena of the region, before analysing stories told by the migrants. If the traditional narrative corpus tends to disappear in the urban context, on the other hand new themes emerge. Therefore, through analisys of the migrants narrative production it is possible to evaluate transformations of 'traditional culture'. The article aims to show that the importance given to the so called "yesterday histories" ("histórias de antigamente") and the references to these narratives depend of people's situation in their new locality. 